\title{
Collective Memory between Tradition and Archive: Josip Mantuani, Heimatschutz and Monument Protection
}

Keywords: Josip Mantuani, Heimatschutz, monument protection, memory, tradition, monument

DOI: $10.4312 /$ ars.13.1.205-218

Monument protection and Heimatschutz played an important role in the process of forming the concept of heritage and the practice of its protection (cf. e.g. Swenson, 2013). The term heritage is relatively new. As its usage was being established, its meaning was expanded: whereas many of the older terms, e.g. monument, referred to individual buildings, the term heritage encompassed not only these but their social function too (Swenson, 2007, 56-57). The semantic differences between the older terms used in various European countries since the early $19^{\text {th }}$ century are said not to have bothered their users; moreover, they did not necessarily signify conceptual differences or differences in the practice of monument protection (Swenson, 2007, 66). From the perspective of the overall development of monument protection, which is greatly characterised by internationalisation and a transition to a broader understanding of the concept of heritage, such an assessment seems justified. However, it is still important, at least from the historiographical perspective, that we examine the discrepancies in terminology, no matter how small, as they often reveal profound conceptual differences among their users.

Researching potential differences or overlaps between the object of protection in monument protection and in Heimatschutz provides a chance to contemplate such issues. A precise definition of a monument, of homeland and of their mutual relationship is necessary, if for no other reason that for so long these two practices have been striving to work together. The first joint session in Salzburg in 1911 was also attended by Josip Mantuani, who covered it in the Slovenec newspaper (Mantuani, 1911b). That article was not his only text on the issue of monument protection. Two years earlier he wrote about the modern principles of monument protection (Mantuani, 1909a-e), and four years later about Heimatschutz (Mantuani, 1914). There is no doubt that his texts aided in the establishment of the framework of contemporary 
heritage protection in Slovenia. ${ }^{1}$ At the same time, a thorough reading of these texts reveals interesting aspects of Mantuani's understanding of the conceptual foundations of practice in that field.

In order to understand them properly, we must discuss at least two more articles by Mantuani: in the first, he contemplated the effects of war on art (Mantuani, 1918a and 1918b), and in the second he contemplated artistic styles (Mantuani, 1915a and 1915b). Though the two articles discuss a much broader issue than the mere protection of heritage, the introductory paragraphs of both connect the topics being covered directly with the issue of monument protection. Thus, in the introduction to the older article, he wonders whether it is even sensible to write about art in a time of war, which he answers affirmatively, pointing out its endangerment as the main reason. This endangerment is a double one: a direct one (the destruction of buildings with artistic and historical significance and their furnishings) and an indirect one (a halt in production due to the altered living conditions) (Mantuani, 1915a, 138). In the second article too, he introduces his line of reasoning with the finding that the maelstrom of war has damaged many works of art, which poses the essential question of their restoration and further conservation (Mantuani, 1918a, 15). In the remainder of both articles Mantuani presents his understanding of art, its social importance and historical development. In his older article he devotes a great deal of attention to the destruction of works of art in the past and present; in his younger article, he presents his understanding of the historical development of art production, which he then relates to the question of how old artistic monuments should be restored, on which the experts of that time were divided. The common thread of both texts is his realisation that contemporary art, in general and in Slovenia, was experiencing a crisis (Mantuani, 1915a, 143; Mantuani 1915b, 187; Mantuani 1918a, 18-19; Mantuani, 1918b, 118-119). In the conclusion of both articles he establishes a clear connection between the crisis and monument protection. He concludes the older article with the idea that war is a "good opportunity" for the much-needed reformation of art, which could be achieved by fulfilling two tasks - the proper restoration of the damaged older artistic monuments and a reform of contemporary art production (Mantuani, 1915b, 195). He concludes the second article in a similar way, namely by advocating the proper restoration of the damaged older artistic monuments, which should serve as an inspiration for the reformation of contemporary artistic production (Mantuani, 1918b, 122).

In the older article, Mantuani explains this mutual relationship between both tasks in greater detail when discussing the importance of Heimatschutz and monument

1 According to some, Mantuani's article on Heimatschutz is one of the three fundamental programme texts of monument protection in Slovenia. The other two were written by France Stele (Pirkovič, 2014). This article is a part of a research study in which I will compare Mantuani's understanding of the conceptual premises of monument protection with those of Stele. 
protection; the two will have to thoroughly restore and conserve the buildings damaged during the war, together with their furnishings and broader surroundings. He specifically points out that "promoting and lifting" art is more important than replacing and restoring damaged works of art (Mantuani, 1915b, 187). Furthermore, he does not view the protection of heritage as important in and of itself, but as an important intermediate step in the reformation of art. Thus, in the conclusion of his article, he writes that "the witnesses to the old culture" will have to be treated with respect and that we will have to summon up all our efforts to conserve them until our own artistic culture receives "new vigour and earnest principles", which will "revive" the new direction based on "immaterial ideals" (Mantuani, 1915b, 195). In order to make sense of this viewpoint, we must be familiar with Mantuani's understanding of art. Mantuani understands art as a mental ability which, at least originally or under ideal circumstances, is not individualized but collective. Art is an expression of the folk aesthetic concept and sentiment. Its essential task is enabling transcendence (Mantuani, 1911a, 7-8). Two conclusions can be drawn from this, which are important for the present discussion. As Mantuani has pointed out, the observer of a work of art must penetrate into the idea behind it in order for the artwork to achieve its purpose; in the process, he/she must disregard its material aspect (Mantuani, 1911a, 7-8). He claims that in modern times an alienation has occurred between the broadest masses as the creators of the aesthetic concept and the artists as the authors of works of art, or, in other words, there is a supremacy of individualism within the context of art; for this reason, old artistic monuments are that much more important, because only through admiring them can the broadest masses come into contact with true art and the artists find inspiration for the reformation of contemporary art (Mantuani, 1911a, 15-16).

Mantuanis five-instalment feuilleton on the modern principles of monument protection, which was published in the Slovenec newspaper in December 1909, was meant to raise the awareness of the broadest public regarding the issue of protection. Hence, Mantuani opens it with the statement that nowadays the protection and prevention of the destruction of historic and artistic monuments is a matter of culture, of manners. Therefore, the question is not whether we should conserve them or not, but how they should be conserved. He considers any opposition to their conservation as a reflection of unbridled free will, of spur-of-the-moment, reckless decisions, and of extreme opportunism. According to him, that was especially typical of previous periods. Regardless, he points out that protection is a rather old phenomenon (Mantuani, 1909a, 1), which he then corroborates by briefly outlining its history. It should be noted that he is usually not talking about the protection of monuments in the modern sense - namely the conservation of the material remains of older periods as witnesses to (art) history - but about the literal conservation and prevention of the destruction 
of buildings built in previous periods, and of their furnishings (Mantuani, 1909a, 1-2; Mantuani, 1909b, 1-2; Mantuani, 1909c, 1). After finishing his outline of the historical development of "the conservation of historical monuments", Mantuani focuses on the issue of the justification of such efforts. He finds it to be unquestionable, stating that all efforts that are the product of years of consistent historical development are culturally justified. He continues by examining their practical justification. In this context, he makes known his view that the conservation of historical monuments is mostly typical of periods that were unable to solve the big challenges of their time (Mantuani, 1909c, 1). He emphasizes that our own age is just as incapable of this as some of the older ones were - as reflected in the lack of new problems and autonomous aesthetic forms and in problems with the material. Since we do not have any newer, better monuments, we must conserve the old ones as long as possible. In this sense, historical monuments are witnesses to bygone life. As witnesses to the authentic regional (heimische) culture, we must conserve them as pristinely as possible (Mantuani, 1909c, 1). Old monuments, be they individual buildings or groups of buildings, testify to the way of life, artistic creation, and aesthetic sentiment of our ancestors, and to their skills of positioning, of making logical use of space, and their knack for ensuring proper and healthy living conditions. Moreover, the conservation of old monuments is a matter of reverence, a sign of the love and respect of one's ancestry. Simultaneously, it also has identifiable "practical consequences" - the chance for foreign tourism to boom (Mantuani, 1909c, $1-2)$. He complements his incentive to protect monuments with a longer reflection on the purely practical aspects of coordinating the demands of modern life with the possibilities of satisfying them in relation to the conservation of older buildings. On the one hand, he tries to be as illustrative as possible, while, on the other substantiates his practice by giving examples of such solutions from foreign countries, mostly from Italy and Germany (Mantuani, 1909c, 2-4). Afterwards, Mantuani discusses the problem of the renovation of older buildings, again confronting the practical aspects, mainly the problem of private ownership and the rights stemming from it, with the conceptual framework of protection. With regard to the latter, he again highlights that old buildings and their furnishings are a reflection of the culture typical of these parts, and that their conservation on the one hand and the further development of their features on the other is an expression of the protection of our own identity. Hence, the conservation of old monuments is also of great national and political importance. The identifiable characteristics of our monuments are not merely a consequence of the requirements of their location, but are, above all, the result of culture, which is propagated by the people. Therefore, it is "common property", which justifies the demands for its protection, i.e. the potential encroachment on the rights of private owners (Mantuani, 1909d, 1-2). At the end of the fourth feuilleton and in half of the final feuilleton, Mantuani focuses on a historical review of the changing attitude 
towards old monuments, this time highlighting in particular the relationship between individual communities and their artists. In his opinion, the periods characterized by powerful art are marked by the fact that such art reflected the needs and demands of all the people, and was not only the result of the individual desires of artists. In those periods, art was born of the essence of the cultures of that time. He again concludes with the finding that this does not apply to contemporary society, which is why it is necessary that we conserve and protect all the monuments that have sprung up from a general culture and art, understandable even to "the lower classes" (Mantuani, 1909d, 2; Mantuani, 1909e, 1).

In his report from the first joint session of monument protection and Heimatschutz, Mantuani links both fields of protection (Mantuani, 1911b). In it, he again highlights the ideas he developed two years earlier and expands them from historical monuments to the homeland: old monuments and the homeland represent that which is autonomous, special and characteristic of our territory and as such must be protected. By expanding the domain of protection to the homeland, he stresses not only the need to protect "things" but also the necessity to preserve "attitudes", which requires a reverent attitude towards "the homeland" and to all that "adorns and characterizes it" (Mantuani, 1911b, 1). At the end he specifically points out that, according to this new theory, "folk art" has the same worth as "fine art" and that he hopes it will encourage some to take up "cultural work" and show an interest in "the movement for the benefit of regional artistic monuments" (Mantuani, 1911b, 3).

In 1914, Mantuani published a comprehensive article in the scientific journal Čas with which he wanted to present "the resistant work" of Heimatschutz. In his opinion, it was needed because the homeland was threatened - since its autonomous nature, its effects or visible signs and products of its own culture were threatened (Mantuani, 1914, 7). He begins by explaining that Heimatschutz as such is nothing new, and that it is not a cultural movement which would impede economic progress. It is an ancient sentiment, which can be seen in folk songs and authorial songs, which contain explicit "homeland scenes and images", based on the folk concept and sentiment. Although such songs are not a deliberate form of Heimatschutz, their descriptions of domestic life and contributions are full of "regional values, images and signs". In Mantuani's opinion, the fact that "the homeland images" have accumulated so inside "a poet's soul" shows that it is a powerful cultural force (Mantuani, 1914, 75-76). Thus, the essence of Heimatschutz is spiritual work, while that part of its practice which focuses on the material aspect is of secondary importance. The conservation and protection of the material expressions of regional culture, which are changeable and fleeting, is not the goal or purpose in itself but only a means, albeit an important one, that enables the conservation of permanent, autonomous characteristics of the homeland (Mantuani, 
1914, 76). The subject of Heimatschutz is the culture as a whole, which Mantuani systematizes into five areas: natural features and beauties, man-made monuments, oral and literary folk tradition and production, folk manners, and folk customs and habits (Mantuani, 1914, 76-77). In Mantuani's opinion, the basic assumptions that provide the content framework of Heimatschutz are the following: firstly, the entire culture is an expression of the characteristics of the homeland or of its identity; secondly, in accordance with the natural law of irrepressible change, the objects created as a reflection of a specific culture are also subject to change; and, thirdly, the spirit that was crucial to their creation is eternal. Therefore, the fundamental rule of Heimatschutz is: "protect the old as long as you can; create new - but only in accordance with the principles of an autonomous culture, because only those principles guarantee the conservation of the regional characteristics and homeland features" (Mantuani, 1914, 78-79). In order to make himself clear, he explicitly points out that the main task of Heimatschutz is not the conservation "of the old in its current form", since antiques will eventually disappear; the most important thing for the future is to focus on the newly created objects (Mantuani, 1914, 79). This context also explains his division of antiques into those that can still function as "witnesses to the current living culture" and those that are being protected "only for scientific reasons or because they bestow a special character to certain landscapes". Therefore, he differentiates between those antiques that are the product of a past culture and are as such interesting only for historiographical reasons, and those that are a reflection of our own culture and are important as "good models" (Mantuani, 1914, 79). Thus, in Mantuani's opinion, the ideal goal of Heimatschutz is "the conservation of the leading principles and of the living, i.e. practically usable, works of art created in accordance with these principles" (Mantuani, 1914, 80). In the rest of the article, he defines individual areas of Heimatschutz in greater detail, constantly circling back to its ideal goal. With regard to the area of natural features and beauties, he stresses that we must prevent the destruction of individual plant and animal species, which are characteristic of our region, and simultaneously of the characteristic local images - the latter in particular evoke aesthetic feelings with their characteristic structure and harmonious relationships between the individual parts (Mantuani, 1914, 80-83). With regard to the monuments created by man, he begins by emphasizing that they are the subjects of Heimatschutz even more than "the natural objects", for they - buildings in particular - represent a reflection of man's cultural reformation of the natural environment. Each image of a place is defined by buildings, which "spring forth from an uncalculating soul of the people and its unforced aesthetic sentiment". That is why they must be protected, because they bear witness to the way of life of our ancestors, of their autonomous culture. However, their conservation is primarily important for imparting "instructions" that should be internalized by the present and future generations. As Mantuani clearly 
points out: the first and most important principle of Heimatschutz is to preserve the local image in the future, not merely by conserving old buildings, but mostly by constructing new ones. According to him, the tasks of Heimatschutz were more important for the future than for the present (Mantuani, 1914, 83-84). It is pointless to stop progress and conserve old buildings, which are characterized by a reflection of "a culture that has faded". Buildings must be adapted to the needs of contemporary life, but we must not alter the overall image of a place (Mantuani, 1914, 88-89). Besides buildings, objects are also included among man-made monuments. As far as these are concerned, Mantuani again makes it clear that Heimatschutz is not about "playing with and rejoicing over archaeological artefacts, but is an essential part of the entire artistic culture of our modern age, to which it should return the regenerative power of folk art to be applied to daily tasks and needs" (Mantuani, 1914, 89). The old, autonomous characteristics of old objects should serve as the ideal model and motif in modern design - that way, despite the fact that the modern product will be an independent work of art, "revived according to tradition", its essence and character will be regional (Mantuani, 1914, 90 and 92). All monuments (immovable and movable alike) have a "living cultural" value only as long as they are a part of the entire culture in which they were created and used. When that changes, the objects are left with an "archival" or "intellectual and scientific" and "artistic and archival value". They are important only for the historian and ethnologist who study them or for practising artists as a source of inspiration for their own products (Mantuani, 1914, 91 and 96). For this reason, he points out that a necessary Heimatschutz measure in the field of immovable heritage is the establishment of an architectural counselling office or an office for reviewing plans, and an open-air museum as "a permanent example of regional buildings" (Mantuani, 1914, 93 and 100-101), while in the field of movable heritage he highlights, on the one hand, the support and enlargement of public museum collections, which will represent a treasure trove of examples for practising artists, and, on the other hand, the promotion of the wearing of national costumes (Mantuani, 1914, 91 and 95). In the fields of oral and literary folk tradition and folk customs and habits, Mantuani explicitly mentions that there is a general rule, namely, to conserve the old and, even more importantly, to promote the use of the genuinely regional in new "formations" (Mantuani, 1914, 96-97). In Slovenia, according to Mantuani, most of the prerequisites have not been fulfilled and we lack the cultural background for the proper operation of Heimatschutz, as described by him; that is why he devotes the final part of the article to thoughts on how that could be achieved. He believes that propaganda is of key importance and that it should be carried out carefully - gradually and systematically. In this process, the key role will be held by the newly established central office, which should organize special lectures that will teach the attendees the proper attitude towards their homeland and, above all, where they should look for their homeland and how it should be understood 
(Mantuani, 1914, 97-98). Furthermore, it will be necessary to involve public authorities and individuals who are interested in the movement for the right reasons and who are not guided by selfish interests (Mantuani, 1914, 98). In order to truly emphasize his understanding of Heimatschutz, he sums up the key points in the conclusion of the article and again notes that Heimatschutz is a cultural movement, which is first and foremost a spiritual movement and only secondly a material one. Specifically, its subject is the entire character of the regional culture - the territory with its natural features and the achievements of human creation - while its mission is the conservation of this character in the future, and not so much the conservation of individual monuments in the present. In order to achieve this protection goal, individuals and groups or organizations, both public and private, must start working together as one as quickly as possible (Mantuani, 1914, 101).

The texts of Mantuani discussed above on the topics of monument protection and Heimatschutz enable us to form a clear picture of his understanding of and attitude towards what we now call heritage. He views buildings with their furnishings and their location, and the various everyday and artistic objects, as a reflection of culture. $\mathrm{He}$ views culture as a set of beliefs, values and sentiments of a specific community. Since culture represents the characteristics of a community, it is the bearer of its identity. Among the different manifestations of culture, Mantuani as an art historian discusses art separately, attributing to it an especially important role, as it enables an individual to rise above the troubles of everyday life. Simultaneously, through its various forms, it also evokes "a sense of homeliness", as do the other bearers of culture. Art makes a first impression on us with its appearance, i.e. its forms, however, Mantuani considers its content, i.e. the idea behind it, to be the essence of art, the same as in the case of culture. The key to understanding Mantuani's attitude towards heritage is his distinction between the idea - which he claims is eternal, unchanging - and form, which is changeable - besides the content, it is also influenced by the materials and techniques used. In periods when the bond between the community and art production (and in the broader sense, the entire cultural production) is alive and strong, ethically justified art (culture) is created. Its outward forms reflect the changing living conditions at a given time, but its essence nevertheless clearly reflects the unchanging spirit of the community, which is its bearer. In such periods, the conservation of the artistic or cultural monuments of previous periods is not necessary, because the community is making its own suitable cultural products. The protection of the material witnesses to bygone times becomes necessary only in artistically or culturally weak periods. That is when old buildings and their furnishings, their arrangement into larger wholes and their positioning, and the multitude of diverse everyday and artistic objects are given exceptional importance as a treasure trove of forms, which the community should 
reinternalize. The outward forms of old monuments are not important in themselves, but merely as the bearers of concepts, values and sentiments, which the community embedded into them in the past. Therefore, old monuments are merely the bearers of patterns and models, which the community has to start using independently, after it "reclaims them as its own", in the production of new buildings and their furnishings, and of everyday and artistic objects. The importance of the material existence of old monuments is merely transitory. Besides serving as a treasure trove of models and patterns, Mantuani also mentions the importance of old monuments in the context of scientific research into them, especially of historiographical and ethnological research; however, it is also evident that he finds that aspect important mostly in connection with the material remains of those periods to which we are no longer linked by "a living culture", and that to him, the knowledge of the history of one's homeland comes second to the true sentiment associated with the homeland. For Mantuani, knowing the details about a specific old monument or understanding its historical context is not as important as adopting a proper, i.e. reverential, attitude towards it as "a sign" of the homeland or of what it is meant to represent, and consequently our identification with it.

Mantuani uses the phrase "historical monument", which is the basic concept of modern monument protection, as outlined by Alois Riegl (1903), ${ }^{2}$ mostly in the sense of a monument created in the past. Besides the fact that he explains it that way in one of his texts (Mantuani, 1914, 91), it can also be discerned from the context of its usage and from the fact that he often uses the phrase "old monument" in its place, or even more often the word "monument" without an adjective. However, in one instance he explicitly points out that monuments are "historical documents; built, chiselled in stone or painted witnesses to a past life, witnesses to a genuine regional culture" (Mantuani, 1909c, 1). He continues by saying that no text, "no matter how graphic and enraptured, can evoke as many accurate mental images and impressions as a historical monument can with its impartial forms and specific location" (Mantuani, 1909c, 1). Mantuani thus believes that the essential task of monuments is to evoke specific, positive emotions, which are triggered by images or impressions. He does not view historical monuments so much as historical sources, but rather as cultural sources. ${ }^{3}$ This does not mean that Mantuani does not consider monuments to have a historical and testimonial value in Riegl's sense of the term, but that he considers this value less important and definitely not the main reason for their protection. In his opinion, a monument, as long as it is connected with the entire and uniform

2 For more on the history of the concept of a (historical) monument and its etymological connection to memory, see e.g. Wibirall (1982).

3 He too uses that expression. Moreover, he views monuments as "witnesses to a genuine regional culture", as "silent cultural sources" (Mantuani, 1909c, 1). 
culture of which it is a product, has "a living cultural importance". When that ceases to be true, it is left with only "a scientific and archival" or "an artistic and archival importance" (Mantuani, 1914, 91). "If we safeguard our monuments and keep developing their features, we preserve our own homeliness, an expression of our own concept and sense of proportion, form and ornaments, created in accordance with the culture, and above all the sense and belief that we need it in order to live in our region, in our climate, for our work and for the distribution of time, etc." (Mantuani, 1909d, 1). The monuments of "ancient cultures", i.e. of cultures that no longer have any "practical bearing" on this day and age, are also protected, but that "legacy" has only an intellectual and scientific importance and is protected as part of "homeland history" (Mantuani, 1914, 96). For Mantuani, monuments are primarily the bearers of cultural continuity, meaning that they represent tradition, something lasting, while their essence is associated with an emotion. Only when that continuity is interrupted, for instance in the case of the remains of a long gone and, consequently, foreign culture, do monuments become the sources of a historical memory, which is founded on knowledge and understanding.

The conceptual foundation of Mantuani's understanding of heritage protection is most clearly evident in his text on Heimatschutz. In it, he frequently points out that it is a "mostly psychological", i.e. spiritual, practice, which is also connected with practice in the material field, but this is of secondary importance. This attitude towards protection is connected with his understanding of culture. He believes that the content is its essence; he calls it folk concept and sentiment, which is said to be more or less unvarying. Even though its manifestational, i.e. material, forms depend on the material and technique and are subject to the passage of time, Mantuani perceives culture as unvarying. Each period produces its own manifestational forms of this culture - cultural artefacts, but its essence stays the same. The protection of cultural artefacts becomes necessary only in those periods in which contemporary production diminishes, for one reason or another, or becomes unsuitable, meaning that its results no longer reflect the idea behind the culture. The aim of protection is not to conserve old cultural artefacts for their own sake, but mainly as models and patterns of the idea they embody. They should serve as an inspiration to contemporary makers of cultural artefacts, who should use them to find a suitable way to realize this all-pervading idea in new, era-appropriate cultural artefacts. They should also serve as a foundation for educating the broadest masses to love their own culture, which, together with the natural environment in which they are living, represents their homeland. Therefore, the aim of protection is to conserve the homeland, as expressed in its "images", "depictions", "signs". Thus, the homeland to be protected by Heimatschutz is to a large extent a fictional landscape, unvarying in essence and independent of time, yet 
complexly linked to a concrete, real and dated landscape (cf. Blickle, 2004). In addition to the cultural artefacts that define it in its present form, it also contains the remains of previous cultures - monuments that embody the memory of its past, its history.

\section{References}

Blickle, P., Heimat. A Critical Theory of the German Idea of Homeland, Woodbridge, Rochester 2004.

Mantuani, J., O modernih načelih ohraniti zgodovinske spomenike, Slovenec. Političen list za slovenski narod XXXVII, No. 281, 9. 12. 1909a, pp. 1-2.

Mantuani, J., O modernih načelih ohraniti zgodovinske spomenike, Slovenec. Političen list za slovenski narod XXXVII, No. 282, 10. 12. 1909b, pp. 1-2.

Mantuani, J., O modernih načelih ohraniti zgodovinske spomenike, Slovenec. Političen list za slovenski narod XXXVII, No. 283, 11. 12. 1909c, pp. 1-4.

Mantuani, J., O modernih načelih ohraniti zgodovinske spomenike, Slovenec. Političen list za slovenski narod XXXVII, No. 284, 13. 12. 1909d, pp. 1-2.

Mantuani, J., O modernih načelih ohraniti zgodovinske spomenike, Slovenec. Političen list za slovenski narod XXXVII, No. 285, 14. 12. 1909e, p. 1.

Mantuani, J., Umetnost v povojih, Slovenec. Političen list za slovenski narod XXXVIII, No. 235, 15. 10. 1910, pp. 2-4.

Mantuani, J., O sociologiji umetnosti, Čas. Znanstvena revija »Leonove družbe« V, No. 1-2, 1911a, pp. 1-16.

Mantuani, J., Čuvajmo domače spomenike (Po zborovanju v Solnogradu), Slovenec. Političen list za slovenski narod XXXIX, No. 230, 7. 10. 1911b, pp. 1-3.

Mantuani, J., Domovinsko varstvo, Čas. Znanstvena revija »Leonove družbe« VIII, No. 2, 1914, pp. 73-101.

Mantuani, J., Umetnost in vojna, Čas. Znanstvena revija "Leonove družbe« IX, No. 3, 1915a, pp. 138-146.

Mantuani, J., Umetnost in vojna II, Čas. Znanstvena revija »Leonove družbe« IX, No. 4, 1915b, pp. 186-195.

Mantuani, J., O umetniških slogih, Dom in svet XXXI, No. 1/2, 1918a, pp. 15-19.

Mantuani, J., O umetniških slogih, Dom in svet XXXI, No. 5/6, 1918b, pp. 117-122.

Pirkovič, J., Sto let v dobro dediščine - izhodišča, pot in sadovi, in: Sto let $v$ dobro dediščine (ed. Gorenc, N.), Ljubljana 2014, pp. 20-35.

Riegl, A., Der moderne Denkmalkultus, sein Wesen und seine Entstehung, Wien, Leipzig 1903. 
Swenson, A., "Heritage", "Patrimoine" und "Kulturerbe": Eine vergleichende historische Semantik, in: Prädikat "Heritage". Wertschöpfungen aus kulturellen Ressourcen (eds. Hemme, D., Tauschek, M., Bendix, R.), Berlin 2007, pp. 53-74.

Swenson, A., The Rise of Heritage. Preserving the Past in France, Germany and England 1789-1914, Cambridge 2013.

Wibiral, N., Ausgewählte Beispiele des Wortgebrauchs von "Monumentum" und "Denkmal" bis Winckelmann, Österreichische Zeitschrift für Kunst und Denkmalpflege XXXVI, Vol. 3-4, 1982, pp. 93-98. 
Katja Mahnič

\section{Kolektivni spomin med tradicijo in arhivom: Josip Mantuani, domovinsko varstvo in varstvo spomenikov}

Ključne besede: Josip Mantuani, domovinsko varstvo, spomeniško varstvo, spomin, tradicija, spomenik

Leta 1911 se je Josip Mantuani udeležil skupnega srečanja o spomeniškem varstvu in domovinskem varstvu v Salzburgu, o čemer je obširno poročal v Slovencu. Čeprav je bilo njegovo delovanje kot člana spomeniškega sveta in direktorja deželnega muzeja brez dvoma osredotočeno na varovanje zgodovinskih spomenikov, je bilo tudi domovinsko varstvo področje, ki mu je bilo zelo blizu. O tem jasno priča besedilo Domovinsko varstvo, ki ga je leta 1914 objavil v znanstveni reviji Čas. Omenjeni besedili, skupaj z njegovim petdelnim podlistkom o modernih načelih spomeniškega varstva, ki ga je konec leta 1909 objavljal v Slovencu, ponujata dober vpogled v Mantuanijevo razumevanje medsebojnega razmerja med spomeniškim in domovinskim varstvom. $\mathrm{V}$ vseh treh besedilih se jasno začrta razlika, ki jo je Mantuani razumel med spomeniki, ki so bili s svojim značajem, obliko in vsebino še usidrani v obstoječo tradicijo, in tistimi, ki jih je razumel le še kot »neme priče« preteklih kultur, z drugo besedo, kot zgodovinske vire. Prvim je pripisoval »živo kulturno« vlogo, druge pa je razumel kot »arhivsko gradivo«. 
Katja Mahnič

\section{Collective Memory between Tradition and Archive: Josip Mantuani, Heimatschutz and Monument Protection}

Keywords: Josip Mantuani, Heimatschutz, monument protection, memory, tradition, monument

In 1911, Josip Mantuani attended a joint meeting for monument protection and Heimatschutz (homeland protection) in Salzburg, which he covered extensively in the Slovenec newspaper. Even though his practice as a member of the Monument Council and director of the Provincial Museum undoubtedly centred on the protection of historical monuments, he was also well acquainted with Heimatschutz. This is clearly shown in his text "Domovinsko varstvo" (Heimatschutz), which he published in the scientific journal Čas in 1914. The two aforementioned texts, along with his five-instalment feuilleton on the modern principles of monument protection, which he published in the Slovenec newspaper in late 1909, provide a good insight into Mantuani's understanding of the mutual relationship between monument protection and Heimatschutz. In all three texts one can clearly discern that Mantuani distinguished between monuments that were still rooted in the existing tradition through their character, form and content, and those he viewed as "silent witnesses" to past cultures, or, in other words, as historical sources. He attributed "a living cultural" role to the former, while viewing the latter as "archival material". 